Journal of

Business and Strategic

Management

(JBSM)

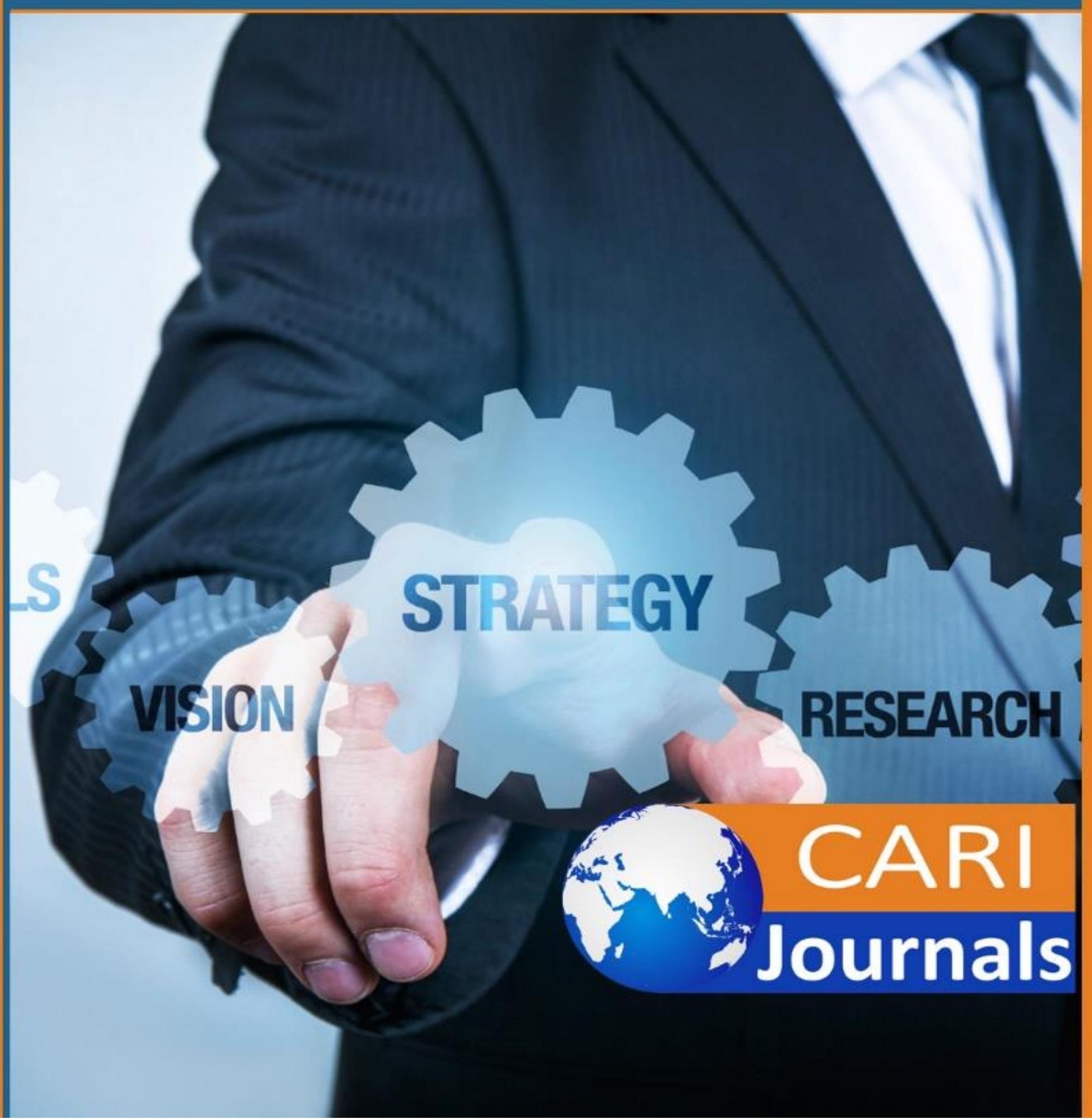


Journal of Business and Strategic Management

ISSN 2520-0402 (Online)

Vol.6, Issue No. 2, pp 1-14, 2021

www.carijournals.org

\title{
Influence of Strategic Change Management on the Performance of County Development Projects in Meru County, Kenya
}

\author{
Lillian Karambu Baariu \\ Corresponding Author's email: lillymainat@gmail.com \\ Dr. Vivian Cherono, \\ Lecturer: School of Business and Economics, \\ Corresponding Author's email: maiywa2000@yahoo.com \\ Abel Moguche, \\ Lecturer: School of Business and Economics, \\ Kenya Methodist University \\ Corresponding Author's email: abel.moguche@kemu.ac.ke
}

\begin{abstract}
Purpose: The purpose of the study was to establish the influence of strategic change management on performance of county government development projects in Meru County, Kenya.

Methodology: The study adopted descriptive design. The target population of the study were 139 respondents comprising 9 sub-county departmental heads, 65 project management committee members, 20 county chief officers and 45 members of county assembly. A sample size of 103 respondents were drawn from the population to participate in the study. The main research tool was questioners. The data was analyses using SPSS. Descriptive statistics mainly percentages and frequency distribution were used for data presentation. Analysis of variance (ANOVA) was used to establish the level of statistical significance of difference between the observed and expected values. Regression analysis was used to estimate the model coefficient while Pearson coefficient of correlation was used to establish the strength of relationship among the variables. Test of hypothesis was also carried out.
\end{abstract}

Results: After carrying out regression analysis, the research indicated that leadership was found to be statistically significant in explaining performance of county governments development projects since a unit change in leadership caused 0.488 units change in performance of county governments development projects as indicated by regression coefficient. The findings further revealed that there exists a positive and significant relationship between leadership and performance of county governments development projects $(r=0.339$; $p$ value $<0.05)$.

Unique contribution to theory, policy and practice: It's recommended that the county government should recruit competent managers to enhance performance of the county development projects. Further, management of county should be include all professionals from all the communities in Kenya

Keywords: Strategic management change, leadership, Performance of county development projects, Meru County. 
Journal of Business and Strategic Management

ISSN 2520-0402 (Online)

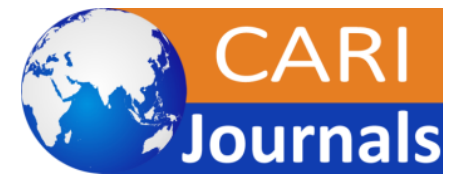

Vol.6, Issue No. 2, pp 1-14, 2021

WwW.carijournals.org

\subsection{INTRODUCTION}

The changes which occur in any environment, where an organization does its operations, whether technologically, the surrounding marketplace, systems of information, the economy worldwide, organization values and political stability greatly affect the Strategic Change Management of the organization. Strategic Change Management systems role is to ensure alignment of processes, structures, behavior and systems of the newly developed strategies (Shimengah, 2018). These methods ensure organizational change is done according to the determined direction of the organization, done in a relatively effective and efficient manner in terms of cost and also ensure completion is done within the targeted time frame work with the achievement of the targeted results (Chanda \& Goyal, 2020).

Strategic change management ensures that business change management is done effectively with leaders at the top, departmental managers and employers highly promoting team work to ensure technologically changes, organizational changes and processes of the organization are smoothly implemented (Nayak \& Sahoo, 2015). For any organization to survive in the prevailing business changes, then business managers must be ready to changes their operations so that they align with the market changes.

Success in the public service management entails maximization of the scarce resources to achieve maximum utility to the beneficiaries. This is reflected by a high performance which then translates to the general growth of the economy (Kariuki, 2014). However, for the public service to show high performance, it must get peoples commitment towards achieving its objectives. According to Kimathi (2016) performance of the organization is key to shareholders, creditors, debtors, management and also the government.

Adoption of strategic change management by public organizations has brought significant effects to their performances. Kunisch \& Huy (2017) argue that due to these changes, organizations have been forced to change their responses to environmental changes, which has thus translated to changes in approach to noble opportunities and threats (Kunisch \& Huy, 2017).

As a result, county governments have to devise ways to put up with these changes in order to gain competitive advantage and boost their profit margins. According to Helfat \& Martin, (2015) despite the fact that there is no framework so far for organizational strategies changes and performance, there are some indications that management changes improve overall performance of the organization. It is this regard that public organizations in Kenya are rapidly embracing strategic changes in management. These changes arise from customer services and delivery of services to the community and clients.

\subsection{Statement of the problem}

The performance of county government on development projects cannot be ignored as these organizations brings services closer to the society and improves the formal societal life. This is evident from several scholarly discourses on the contribution of county government in different social contexts (Koitie, 2015). Accordingly, some studies like Kitsios and Kamariotou (2017) have observed that county development projects continue to respond to the diverse and growing demands by the society even with limited resources in this sector. County governments continue to experience unsatisfactory development projects performance which may be attributable to 
Journal of Business and Strategic Management

ISSN 2520-0402 (Online)

Vol.6, Issue No. 2, pp 1-14, 2021

$\underline{\text { www.carijournals.org }}$

ineffective leadership and consequently poor performance even as society increasingly continue to demand for sustainable services.

Kariuki (2014) found that the performance of county government development projects in many developing countries especially in Africa was poor. Though some studies have linked performance to social contexts (Kimathi, 2016). The relationship between strategic change management and performance of development projects of county governments in Kenya has received less attention; further, studies on strategic change management in the county's context are even scarce.

Therefore, this study sought to examine the influence of strategic change management practices on the performance of county development projects in Kenya.

\subsection{The purpose of the study}

The purpose of this study was to establish the influence of strategic change management on performance of county government development projects in Kenya.

\subsection{Hypothesis}

This study strived to respond to the following hypothesis:

Ho: There is no significant relationship between leadership and performance of county governments development projects in Kenya.

\subsection{LITERATURE REVIEW}

\subsection{Theoretical framework}

\section{Path-Goal Theory}

Path-goal theory, originally developed by Martin G. Evans in 1970 and later modified by Robert House in 1971, was designed to identify a leader's most practiced style as a motivation to get subordinates to accomplish goals (Farhan, 2018). Path-goal theory is primarily a theory of task and person oriented supervisory behavior which does not concern the leadership of entire organization, rather only the specified work unit with regards to achievement of a specific goal at a specific time (Rowold, 2014).

In this theory, leader behavior is acceptable and satisfying to the extent that the subordinates see such behavior either as an immediate source of satisfaction or instrument to future satisfaction (Farhan, 2018). The theory assumes that subordinate will be motivated if they think they are capable of performing their work, if they believe their efforts will result in a certain outcome, and if they believe that the payoffs for doing their work are worthwhile (Rowold, 2014).

According to this theory, a leader behavior is predicted to be motivational if: (1) it reduces roadblocks that interfere with goal accomplishment (2) it provides guidance and support needed by subordinates (3) it ties meaningful rewards to goal accomplishment (Saide, Indrajit \& Najamuddin, 2019). According to path-goal leadership, the effectiveness of leader is influenced by the interaction of leader behaviors (directive, supportive, participative and achievementoriented) with two types of contingency factors including, subordinate characteristics and environment, that cause one leadership style to be more effective than another (Farhan, 2018). 
Journal of Business and Strategic Management

ISSN 2520-0402 (Online)

Vol.6, Issue No. 2, pp 1-14, 2021

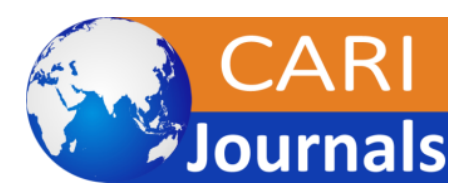

www.carijournals.org

Path Goal theory claims that the most successful leaders are those who keep their employees and subordinates motivated defining and making the path of work clear to them through their clear vision. Thus, leader role is to align individual goals with organizational goals and facilitate the achievement of such goals by encouraging them to achieve these goals, clarifying the path towards goal attainment and ensuring that goals are valuable to followers (Farhan, 2018).

County government leaders should take a key role by creating working environments that reduce barriers that hinder implementation of the desired change status, provide guidance to the employees by clarifying unclear and uncertain paths, and motivating employees to work tirelessly towards the desired organizational change status.

\subsection{Empirical review}

\section{Leadership on Performance}

According to Tyssen, Wald and Spieth (2014), leadership is one of the key factors necessary to attain the desired level of performance. The relationship between performance and leadership is so essential such that it can influence service delivery in county governments; hence county governments should strengthen their leadership. Organizations are focusing on improving their leadership styles, in order to boost returns on investment. They are adopting the art of maintaining constant communication with clients to enhance accountability (Pretorius, Steyn \& Bond-Barnard, 2018).

However, challenges such as diversity in cultural differences in leadership and communities served have posed a challenge in service delivery (Buba \& Tanko, 2017). A leadership which manages to come up with partnering relationship which will lead to development of strategic changes clearly articulating the mission of the firm and leads to improved performance is all what is needed in the government leadership. Being physically available in the society and maintaining consistency in offering accountable services to citizens and employees is what is mostly required in government organizations (Pretorius et al. 2018).

The leadership of the organization should always have a clear and offer consistent communication of its mission and the services it offers as it strives to address specific wants in their area of operation. One of the main challenges in developing countries especially African states is a shortage in experienced leadership which does not put much value on measures of getting skills and knowledge. This has been one of the main reasons poor implementation of government related projects as a result of poor leadership in government departments (Yang, Huang \& Hsu, 2014).

Each of the country's education system needs a setup which meets performance management demands of that country which then suggests urgent prioritization of development of employees within government departments. Also, a need of attraction and maintenance of skill evaluation is required in government departments (Patel, Thorgren \& Wincent, 2015).

The importance created on capacity building which was achieved by trainings was one of the major strategies that led to completion of government projects in Tanzania while a close look at one of West African States, Ghana insufficient capacity led to late implementation of government projects (Buba \& Tanko, 2017). For government projects to be effectively and efficiently implemented, employees need to be experienced with the necessary knowledge and skill set. Absence of 
Journal of Business and Strategic Management

ISSN 2520-0402 (Online)

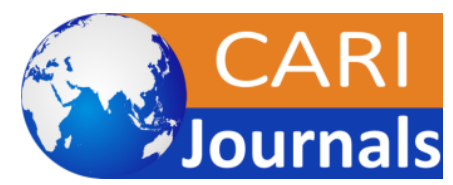

Vol.6, Issue No. 2, pp 1-14, 2021

$\underline{\text { www.carijournals.org }}$

employees with the necessary project management skills and experience cannot be easily substituted by training and employing new staff (Yang et al. 2014).

Employees with the required skills are not always incentivized to joining the public sector making it hard for the public sector to favorably compete with the private sector since also the conditions of employment and salary system in the private sector are far much better than those on the public sector. Many experienced employees leave the public sector for greener pastures elsewhere which then worsens the situation (Oyaya, 2016).

The leaders in various governments, mostly in developing countries, departments should be experienced in designing, managing and operating accounting in government, implementing projects and managing the budgeting and financing systems. High experience in government departments by leaders should always be in consideration during the implementation of strategic changes in government departments for them to improve on performance (Pilkiene \& Müller, 2018). Leaders in managerial positions should be experienced and be able to operate the latest computerized systems of finance in a government budgeting and accounting environment (Oyaya, 2016).

Poor performance by leaders of public organizations has led to governance of weak projects, technical areas of development and inexperienced leaders who cannot be depended to formulate and implement strategic changes (Zhang \& Skibniewski, 2018). Most developing countries need to formulate strategies which ensure experience is gained through training, development in management, human resource management and structural adjustments in the organization. The organizations leadership should put up measures to ensure efficiency in managing and implementing projects and also developing their training capacity (Buba \& Tanko, 2017).

Independent variables

\begin{tabular}{|l|}
\hline Leadership \\
- Competent Managers \\
- Inclusive Professionals \\
- Teamwork \\
\end{tabular}

\section{Dependent variables}

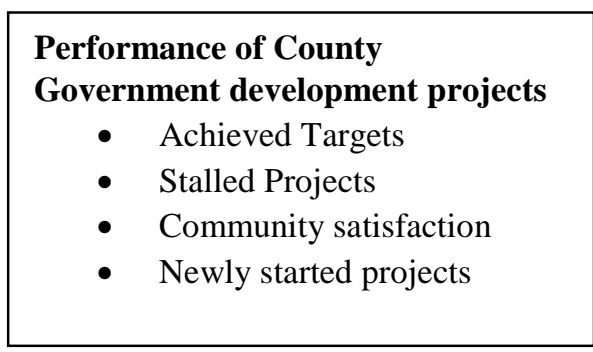

\section{Figure 1 Conceptual Framework}

\subsection{Research Gap}

Various studies have been conducted on the newly devolved government structures. Wamae (2014) studied the role of procurement function in enhancing performance on county governments. The study focused on procurement function and thus presenting a conceptual gap. The current study focused on strategic change management. Mugambi and Theuri (2014) studied the challenges encountered by devolved governments in Kenya in the budget preparation process. The study found that the planning process was not adequately done as per the stipulated guidelines. The study was biased on budget preparation process whereas the current study focused on strategic 
Journal of Business and Strategic Management

ISSN 2520-0402 (Online)

Vol.6, Issue No. 2, pp 1-14, 2021

www.carijournals.org

change management. Wambua (2014) examined decentralization of governments operations and services delivery by sector. The study found that there was an overlap in the role of the national government in delivery of services of some functions. The study focused on government operations only while the current study focused on strategic change management. Most of the existing studies have researched on areas of management practices on organization's performance (Nyandiko, 2020) and are based on foreign countries. Evidence from the previous literature shows that strategic management practices has not been effectively studied. The researcher is not aware of any research on the strategic management practices more so in the county government of Meru. This gap has further resulted in recommendation by Mumanyi (2014) that more studies need to be carried out primarily to investigate the relationship between strategic change management and performance of county government funded projects.

\subsection{METHODOLOGY}

The study adopted a descriptive design. The target population of this study was 139 staff of Meru County government consisting 9 sub-county departmental heads, 65 project management committee members, 20 county chief officers and 45 members of county assemblies. The study adopted stratified sampling technique because the target population were heterogeneous and everybody was given an equal chance of participating in the study. Therefore, the sample size for the study was 139 respondents.

The study collected quantitative data using a self-administered questionnaire that was administered to the targeted respondents. A questioner for the county staff was constructed to capture relevant information on the objective of the study. Since the study was considered to be based response Likert scale was used. To ensure the information was rich and more comprehensive interviews schedules were prepared to triangularise the data obtained.

The Cronbach alpha method was used for the reliability test of each of the research concepts of strategic change management and the reliability of questionnaire was confirmed by the result generated from Cronbach alpha test. (Cooper \& Schindler, 2011 cited in Taber, 2018) advises that a Cronbach alpha of at least 0.7 is acceptable. The reliability of the questionnaire was greater than 0.7 and therefore was considered reliable for the study. To enhance reliability of the instruments test, factor analysis was used. Factor analysis was conducted to ensure that all the items in each instrument were based on the study and those variables found to have a factor loading of 0.4 and above were retained for further analysis. Factor analysis therefore aided the researcher with the only items that corresponded to the subject dependent on their factor loadings.

Data was analysed using statistical package for social science, (SPSS) version 20.0. Data analysis was carried out using frequencies, percentages. Regression and correlation. The results were presented in form of tables. The study used multiple regression analysis to show the effect and influence of the independent variable. 
Journal of Business and Strategic Management

ISSN 2520-0402 (Online)

Vol.6, Issue No. 2, pp 1-14, 2021

www.carijournals.org

\subsection{FINDINGS AND PRESENTATION}

\subsection{Descriptive Statistics}

\subsubsection{Leadership}

Table 1: Influence of leadership on the performance

\begin{tabular}{|c|c|c|c|c|c|c|c|}
\hline Opinion & SD & D & $\mathbf{N}$ & $\mathbf{A}$ & $\mathbf{S A}$ & Mean & SD \\
\hline $\begin{array}{l}\text { There are } \\
\text { competent to } \\
\text { managers } \\
\text { enhance } \\
\text { performance of the } \\
\text { county }\end{array}$ & $6(6.8 \%)$ & $3(3.2)$ & $9(10.2 \%)$ & $33(37.5 \%)$ & $37(42.0 \%)$ & 4.05 & 0.134 \\
\hline $\begin{array}{l}\text { The management } \\
\text { of county is } \\
\text { inclusive of all } \\
\text { professionals from } \\
\text { all the communities } \\
\text { in Kenya }\end{array}$ & $3(3.4 \%)$ & $3(3.4 \%)$ & $18(20.5 \%)$ & $27(30.7 \%)$ & $37(42.0 \%)$ & 4.05 & 0.134 \\
\hline $\begin{array}{l}\text { There's teamwork } \\
\text { from management } \\
\text { within the county } \\
\text { government }\end{array}$ & $1(1.1 \%)$ & $4(4.5 \%)$ & $11(12.5 \%)$ & $49(55.7 \%)$ & $23(26.1 \%)$ & 4.01 & 0.823 \\
\hline $\begin{array}{l}\text { Employees } \\
\text { participate in } \\
\text { decision making of } \\
\text { the county } \\
\text { government } \\
\text { projects }\end{array}$ & $0.0 \%$ & $5(5.7 \%)$ & $21(23.9 \%)$ & $26(29.5 \%)$ & $36(40.9 \%)$ & 4.06 & 0.939 \\
\hline $\begin{array}{l}\text { The management } \\
\text { team promotes and } \\
\text { develops the right } \\
\text { people to promote } \\
\text { change }\end{array}$ & $5(5.7 \%)$ & $8(9.1 \%)$ & $9(10.2 \%)$ & $32(36.2 \%)$ & $34(38.6 \%)$ & 3.93 & 1.172 \\
\hline $\begin{array}{l}\text { The organizational } \\
\text { leaders are creative } \\
\text { and innovative in } \\
\text { ensuring successful }\end{array}$ & $3(3.4 \%)$ & $7(8.0 \%)$ & $10(11.4 \%)$ & $32(36.4 \%)$ & $36(40.9 \%)$ & 4.03 & 1.077 \\
\hline
\end{tabular}


Journal of Business and Strategic Management

ISSN 2520-0402 (Online)

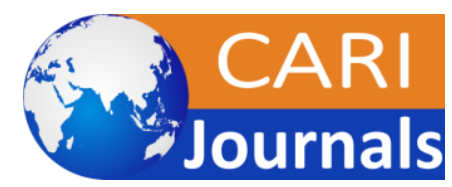

Vol.6, Issue No. 2, pp 1-14, 2021

www.carijournals.org

\begin{tabular}{|l|l|l|l|l|l|l|l|}
\hline $\begin{array}{l}\text { change } \\
\text { introduction. }\end{array}$ & & & & & & & \\
\hline
\end{tabular}

The study findings in table 1 indicate that 37(42.0\%) of the respondents strongly agreed on the statement that there are competent managers to enhance performance of the county with a mean of 4.05 and Standard deviation of 0.134 . They also strongly agree by supporting the opinion statement that management of county is inclusive of all professionals from all the communities in Kenya with a mean of 4.05 and Standard deviation of 0.134 . Most of the respondenst,49(55.7\%) agreed with the opinion statement that there's teamwork from management within the County Government with a mean of 4.01 and Standard deviation of $0.823 .36(40.9 \%)$ of the respondents strongly agreed with the opinion statement that employees participate in decision making of the county government projects with a mean of 4.06 and Standard deviation of 0.939. 34(38.6\%) of the respondents also agreed with the statement that the management team promotes and develops the right people to promote change. Lastly, the 36(40.9\%) of the respondents also strongly agreed with the statement that the organizational leaders are creative and innovative in ensuring successful change introduction with a mean of 4.03and Standard deviation of 1.077. The findings are in line with Tyssen, Wald and Spieth (2014) who revealed that leadership is one of the key factors necessary to attain the desired level of performance. The relationship between performance and leadership is so essential such that it can influence service delivery in county governments; hence county governments should strengthen their leadership.

\subsection{Multiple Regression Analysis}

\subsubsection{Model Summary}

Table 2: Model Summary for leadership and performance of county development projects

\begin{tabular}{lllll}
\hline Model & R & R Square & $\begin{array}{l}\text { Adjusted } \\
\text { Square }\end{array}$ & $\begin{array}{l}\text { R Std. Error of the } \\
\text { Estimate }\end{array}$ \\
\hline 1 & $.893(\mathrm{a})$ & .797 & .785 & .57765 \\
\hline
\end{tabular}

The study conducted a multiple regression analysis and from the above regression model, holding leadership and performance of county development project constant at zero, the performance of county government development project in in Meru County was 1.147. A unit change in leadership lead to 0.488 units change in performance of County development project. This shows that there is a positive relationship between leadership and performance of County development project in Meru County, Kenya. 
Journal of Business and Strategic Management

ISSN 2520-0402 (Online)

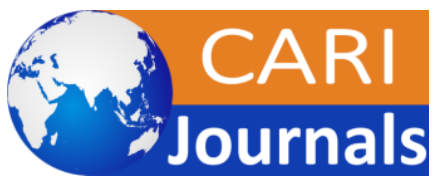

Vol.6, Issue No. 2, pp 1-14, 2021

Www.carijournals.org

4.2.3 ANOVA for leadership and Performance of county development projects

Table 3. ANOVA for Strategic change management on the Performance of county development projects

\begin{tabular}{|c|c|c|c|c|c|c|}
\hline Model & & $\begin{array}{l}\text { Sum of } \\
\text { Squares }\end{array}$ & df & Mean Square & $\mathbf{F}$ & Sig. \\
\hline & Regression & 21.150 & 1 & 21.150 & 22.963 & $.000^{\mathrm{b}}$ \\
\hline & Residual & 79.213 & 86 & .921 & & \\
\hline & Total & 100.364 & 87 & & & \\
\hline
\end{tabular}

The ANOVA analysis in Table 3 presents the influence of leadership variables on performance of County development projects. The results presented a p-value of 0.000 which was less than 0.05 . This indicated that the model was statistically significant in explaining the impact of leadership on the performance of County government development projects. It is therefore concluded that the leadership had significant combined effects on performance of County development projects.

The significance of the model was reaffirmed by the goodness of fit tests whereby the coefficient of determination ( $\mathrm{R}$ square) of 0.797 confirmed that the model explained $89.3 \%$ of the variation or change in the performance of county development projects. The adjusted R square of 0.785 did not make a significant difference since the model now explained $78.5 \%$ of the variations. The coefficient of determination ( $\mathrm{R}$ square) of 0.797 indicated that the model explained $79.7 \%$ of the variations in the dependent variable. This meant that the linear model was a good fit in explaining the relationship between leadership and performance of county development projects.

4.2.4 Regression Coefficient for leadership and performance of County development projects

Table 4: Regression Analysis Results for leadership and performance of county development projects

\begin{tabular}{llllll}
\hline & \multicolumn{2}{l}{$\begin{array}{l}\text { Unstandardized } \\
\text { Coefficients }\end{array}$} & Btandardized & & \\
& B & Std. Error & Beta & Sig. \\
& 1.147 & 3.93 & & 2.915 & .000 \\
\hline Constant) & .488 & .255 & .663 & 1.908 & .001 \\
\hline
\end{tabular}

The standardized coefficients assess the contribution of leadership towards the prediction of the performance, since they have been converted in the same scale to show comparison. The result 
Journal of Business and Strategic Management

ISSN 2520-0402 (Online)

Vol.6, Issue No. 2, pp 1-14, 2021

www.carijournals.org

indicates that leadership having the highest beta of 0.663 has the largest influence on performance of county government development project. The t-test statistic shows that leadership significant since $\mathrm{p}<0.05$.

\subsection{SUMMARY, CONCLUSION AND RECOMMENDATION}

\subsection{Summary of the findings}

Descriptive statistics was used to analyze leadership and other subsequent analysis was done. The results showed the average mean was above 3.0 this meant that most of the respondents agreed with statements concerning the influence of leadership on the performance of county governments development projects in Meru County, Kenya.

Inferential statistical methods were used to arrive at the findings where deductions and relationships were established. After carrying out regression analysis, the research indicated that leadership was found to be statistically significant in explaining performance of county governments development projects since a unit change in leadership caused 0.488 units change in performance of county governments development projects as indicated by regression coefficient. The findings further revealed that there exists a positive and significant relationship between leadership and performance of county governments development projects $(\mathrm{r}=0.339$; $\mathrm{p}$ value < $0.05)$.

\subsection{Conclusions}

The rationalization for the study of this nature could not be undermined as county governments brings services closer to the society and improves the formal societal life. This is evident from several scholarly discourses on the contribution of county government in different social contexts (Koitie, 2015). The degree at which the counties have continued to experience unsatisfactory development project which may be attributed to ineffective leadership has got the attention of the researcher which was the key driver for carrying out the research.

The research heavily relied on quantitative data with supplement of qualitative data to examine the contribution of leadership on performance of county development projects. The finding of the study found leadership to influence performance of county governments development projects in Meru County, Kenya. The study therefore concludes that there are competent managers to enhance performance of the county. It also concluded that management of county is inclusive of all professionals from all the communities in Kenya

\subsection{Recommendations}

With respect to the findings of this study, it is recommended that the county government should recruit competent managers to enhance performance of the county development projects. In addition, management of county governments should be include all professionals from all the communities in Kenya.

\subsection{Suggestions for further studies}

The study evaluated how strategic change management influence performance of county government development projects in Meru County, Kenya. The study therefore suggests that 
Journal of Business and Strategic Management

ISSN 2520-0402 (Online)

Vol.6, Issue No. 2, pp 1-14, 2021

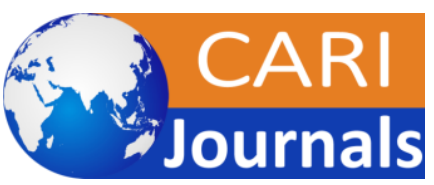

www.carijournals.org

further studies to be carried out that focus on different conceptualization of strategic change management to see how they influence the performance of the County government.

\section{REFERENCES}

Ackerman, B., \& Stuart, E. A. (2019). Implementing statistical methods for generalizing randomized trial findings to a target population. Addictive behaviors, 94, 124-132.

Adams, F. G., \& Graham, K. W. (2017). Integration, knowledge creation and B2B governance: The role of resource hierarchies in financial performance. Industrial Marketing Management, 63, 179-191.

Akhtar, D. M. I. (2016). Research design. Research Design (February 1, 2016).

Almeida, M. D. G. M. C., \& Coelho, A. F. M. (2019). The antecedents of corporate reputation and image and their impacts on employee commitment and performance: The moderating role of CSR. Corporate Reputation Review, 22(1), 10-25.

Alvarez, S. A., \& Barney, J. B. (2017). Resource-based theory and the entrepreneurial firm. Strategic entrepreneurship: Creating a new mindset, 87-105.

Anantatmula, V. S., \& Rad, P. F. (2018). Role of organizational project management maturity factors on project success. Engineering Management Journal, 30(3), 165-178.

Buba, S. P. G., \& Tanko, B. L. (2017). Project leadership and quality performance of construction projects. International Journal of Built Environment and Sustainability, 4(2).

Chanda, U., \& Goyal, P. (2020). A Bayesian network model on the interlinkage between Socially Responsible HRM, employee satisfaction, employee commitment and organizational performance. Journal of Management Analytics, 7(1), 105-138.

Cram, W. A., \& D'arcy, J. (2017). Organizational information security policies: a review and research framework. European Journal of Information Systems, 26(6), 605-641.

Faber, J., \& Fonseca, L. M. (2014). How sample size influences research outcomes. Dental press journal of orthodontics, 19(4), 27-29.

Farhan, B. Y. (2018). Application of path-goal leadership theory and learning theory in a learning organization. Journal of Applied Business Research (JABR), 34(1), 13-22.

Freeman, R. E. (2015). Stakeholder theory. Wiley encyclopedia of management, 1-6.

Freeman, R. E., \& Dmytriyev, S. (2017). Corporate social responsibility and stakeholder theory: Learning from each other. Symphonya. Emerging Issues in Management, (1), 7-15.

Freeman, R. E., Phillips, R., \& Sisodia, R. (2020). Tensions in stakeholder theory. Business \& Society, 59(2), 213-231.

Greenwood, R., \& Hinings, C. R. (2017). Understanding strategic change: The contribution of archetypes. Academy of management Journal. 
Journal of Business and Strategic Management

ISSN 2520-0402 (Online)

Vol.6, Issue No. 2, pp 1-14, 2021

www.carijournals.org

Gu, V. C., Hoffman, J. J \& Schniederjans, M. J. (2014). The effects of organizational culture and environmental pressures on IT project performance: A moderation perspective. International Journal of Project Management, 32(7), 1170-1181.

Gul, Z. (2015). Impact of employee commitment on organizational development. FWU Journal of Social Sciences, 9(2), 117-124.

Gürel, E., \& Tat, M. (2017). SWOT analysis: a theoretical review. Journal of International Social Research, 10(51).

Helfat, C. E., \& Martin, J. A. (2015). Dynamic managerial capabilities: Review and assessment of managerial impact on strategic change. Journal of management, 41(5), 1281-1312.

Heppner, P. P., Wampold, B. E., Owen, J., \& Wang, K. T. (2015). Research design in counseling. Cengage Learning.

Huang, Y., \& Beck, J. L. (2018). Full Gibbs sampling procedure for Bayesian system identification incorporating sparse Bayesian learning with automatic relevance determination. Computer-Aided Civil and Infrastructure Engineering, 33(9), 712-730.

Ivey, J. (2015). How important is a conceptual framework?. Pediatric nursing, 41(3), 145-147.

Kariuki, M. R. (2014). Strategic change management practices and service delivery at the Cooperative Bank of Kenya (Doctoral dissertation).

Kibe, C. W. (2014). Effects of communication strategies on organizational performance: A case study of Kenya Ports Authority. European journal of business and management, 6(11), 610 .

Kimathi, F. M. (2016). Factors Influencing Strategic Change Management Practices At Coca Cola Company In Kenya (Doctoral dissertation, University of Nairobi).

Kitsios, F., \& Kamariotou, M. (2017). Strategic Change Management in Public Sector Transformation: The Case of Middle Manager Leadership in Greece. In Proceedings of BAM Conference 2017 (pp. 73-78).

Koitie, E. J. (2015). Strategic change management practices and the performance of constitutional commissions in Kenya (Doctoral dissertation, University of Nairobi).

Kunisch, S., \& Huy, Q. N. (2017). Time in strategic change research. Academy of Management Annals, 11(2), 1005-1064.

Lau, P. Y. Y., \& Chong, C. L. (2017). Ethical work climate, employee commitment and proactive customer service performance: Test of the mediating effects of organizational politics. Journal of Retailing and Consumer Services, 35, 20-26.

Leuthold, L. A., \& Thomas, A. (2015). New microfluidic-based sampling procedure for overcoming the hematocrit problem associated with dried blood spot analysis. Analytical chemistry, 87(4), 2068-2071. 
Journal of Business and Strategic Management

ISSN 2520-0402 (Online)

Vol.6, Issue No. 2, pp 1-14, 2021

www.carijournals.org

Mathew, G. C., Prashar, S., \& Ramanathan, H. N. (2018). Role of spirituality and religiosity on employee commitment and performance. International Journal of Indian Culture and Business Management, 16(3), 302-322.

Mugambi, K. W., \& Theuri, F. S. (2014). The challenges encountered by county governments in Kenya during budget preparation. IOSR Journal of Business and Management, 16(2), 128134.

Müller, J., \& Kunisch, S. (2018). Central perspectives and debates in strategic change research. International Journal of Management Reviews, 20(2), 457-482.

Müller, R., Pemsel, S., \& Shao, J. (2014). Organizational enablers for governance and governmentality of projects: A literature review. International Journal of Project Management, 32(8), 1309-1320.

Mumanyi, E. A. L. (2014). Challenges and opportunities facing SACCOs in the current devolved system of government of Kenya: A case study of Mombasa County. International Journal of Social Sciences and Entrepreneurship, 1(9), 288-314.

Nakano, D., \& Muniz Jr, J. (2018). Writing the literature review for empirical papers. Production, 28.

Njihia, E., \& Mwirigi, F. M. (2014). The effects of enterprise resource planning systems on firm's performance: A survey of commercial banks in Kenya. International journal of business and commerce, 3(8), 120-129.

Nyandiko, N. O. (2020). Devolution and disaster risk reduction in Kenya: Progress, challenges and opportunities. International Journal of Disaster Risk Reduction, 51, 101832.

Oyaya, W. (2016). Influence of Leadership Style on Performance of Construction Projects: A Case of Housing Projects in Westlands Sub-county, Nairobi, Kenya (Doctoral dissertation, Master's Thesis, University of Nairobi, Nairobi, Kenya).

Patel, P. C., Thorgren, S., \& Wincent, J. (2015). Leadership, passion and performance: a study of job creation projects during the recession. British Journal of Management, 26(2), 211-224.

Pilkienè, M., \& Müller, R. (2018). The governance of horizontal leadership in projects. International Journal of Project Management, 36(7), 913-924.

Pretorius, S., Steyn, H., \& Bond-Barnard, T. J. (2018). Leadership styles in projects: Current trends and future opportunities. South African Journal of Industrial Engineering, 29(3), 161-172.

Qiu, Y., Shaukat, A., \& Tharyan, R. (2016). Environmental and social disclosures: Link with corporate financial performance. The British Accounting Review, 48(1), 102-116.

Rowold, J. (2014). Instrumental leadership: Extending the transformational-transactional leadership paradigm. German Journal of Human Resource Management, 28(3), 367-390.

Saide, S., Indrajit, R. E., \& Najamuddin, N. (2019). A theoretical and empirical validation of information technology and path-goal leadership on knowledge creation in university: Leaders support and social media trend. Journal of science and technology policy management. 
Journal of Business and Strategic Management

ISSN 2520-0402 (Online)

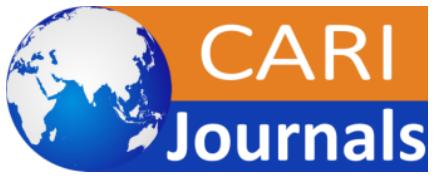

Vol.6, Issue No. 2, pp 1-14, 2021

WwW.carijournals.org

Seddon, P. B. (2014). Implications for strategic IS research of the resource-based theory of the firm: A reflection. The Journal of Strategic Information Systems, 23(4), 257-269.

Shimengah, M. M. (2018). Influence of Strategic Leadership Practices on Service Delivery Within County Governments in Kenya: A Literature Review. Journal of Strategic Management, 3(1), 1-13.

Stanley, D. J., \& Meyer, J. P. (2016). Employee commitment and performance. In Handbook of employee commitment. Edward Elgar Publishing.

Taber, K. S. (2018). The use of Cronbach's alpha when developing and reporting research instruments in science education. Research in Science Education, 48(6), 1273-1296.

Tyssen, A. K., Wald, A., \& Spieth, P. (2014). The challenge of transactional and transformational leadership in projects. International Journal of Project Management, 32(3), 365-375.

Varpio, L., Paradis, E., Uijtdehaage, S., \& Young, M. (2020). The distinctions between theory, theoretical framework, and conceptual framework. Academic Medicine, 95(7), 989-994.

Wamae, J. W. (2014). Role of procurement function in enhancing performance in devolved government: A case of Machakos County. International Journal of Social Sciences and Entrepreneurship, 1(11), 168-190.

Yang, L. R., Huang, C. F., \& Hsu, T. J. (2014). Knowledge leadership to improve project and organizational performance. International Journal of Project Management, 32(1), 40-53.

Yang, L. R., Huang, C. F., \& Hsu, T. J. (2014). Knowledge leadership to improve project and organizational performance. International Journal of Project Management, 32(1), 40-53.

Zhang, L., \& Skibniewski, M. J. (2018). Perceiving interactions and dynamics of safety leadership in construction projects. Safety science, 106, 66-78. 